\title{
Evaluation the Susceptibility of Metformin Drug and Pollen grain of Typha domengensis (Typha) on Prevention of Damage in octa4 gene Which Induced by Mitomycin c in Some Organs in Male Albino Rats
}

\author{
Ghufran Mershoud Latef Alobaidy $(\mathrm{MBChB})^{1}$ and Zubaida Adnan AL-
} $\operatorname{Jashammy}(\mathrm{PhD})^{2}$

\begin{abstract}
Background: Living organisms are permanently exposed to internal and external factors that damage DNA. This damage, if not repaired, can lead to the mutation which cause verius diseases and cellular death. Therefore,the use of many plants or their products has been adopted as aprotective material against genetic toxicityof certain drugs.

Objective:Examined the susceptibility of both metformin and pollen grain solution to the prevention of damage in octa4 gene and mitomycin $\mathrm{C}$, In order to be adopted as materials available and cheap to prevent damage to genetic material and the result of the use of human drugs.

Patients and Methods: was used 25 white males rats for 4 weeks obtained from the College of Veterinary Medicine / University of Baghdad and ages ranging from (10-12) weeks. The rats were divided into 5 groups. the control group was drip with distilled water as well as injected The second group was treated with mitomycin $(0.001 \mathrm{ml})$ was injected subcutaneously weekly for 30 days. while the third group was orally injected with metformin with a concentration of $500 \mathrm{mg} / \mathrm{kg}$ with mitomycin , while the fourth group was treated with mitomycin and water solution for pollen at $0.1 \mathrm{~g} / \mathrm{mL}$ per animal. while the fifth group included rats treated with mitomycin with metformin and water solution for pollen. The animals were anesthetized and the kidney and liver were removed. The DNA extraction process was investigated and the presence of the octa4 gene was investigated using a special technique and PCR technique.The tissues like liver, kidney and testies were collected for study the expression of Oct 4 gene.

Results: The C. papyrus pollon extract along with metformin is effective against mitomicine $\mathrm{C}$ induced animals. Oct 4 it has been protected from mitomycin damage in both the kidney and liver tissue compared to the testis of the animals treated with $C$. papyrus pollon extract and metformin. $C$. papyrus pollen grain producing an effective and safe product, and further research is required in addition to the aggregate value to the native plants.

Conclusion: In the present study, $C$. papyrus pollon extract along with metformin is effective against mitomicine $\mathrm{C}$ induced animals. Oct 4 expression was significantly higher in the kidney and liver tissue of the animals treated with $C$. papyrus pollon extract and metformin. The result of the present study clearly indicates that $\mathrm{C}$. papyrus reduces blood
\end{abstract}


glucose levels, producing an effective and safe product, and further research is required in addition to the aggregate value to the native plants.

Keywords: DNA damaged, mitomycin c, Cyperus papyrus, Oct 4 gene.

Corresponding Author: zubaidabiology@gmail.com

Received: $16^{\text {th }}$ September 2018

Accepted: $13^{\text {th }}$ November 2018

${ }^{1,2}$ College of Education and Applied Science - University of Tikrit - Salahaddin - Iraq.

\section{Introduction}

Every day, genome integrity is challenged by DNA damage from both environmental sources and endogenous agents [1]. As a result of this, the DNA of each cell gathers thousands of lesions every day. These accumulated lessions or extensive damage can cause various diseases or abnormalities such as cancer [2], tumor development, arrest cell cycle progression [3] .This DNA damaged should be removed so that the cell function and proliferate normally [1,4]. This damage essential to be repaired to allow polymerases (RNA and DNA) to precisely read and duplicate the information in the genome. Fortunately, cells contain several DNA repair mechanisms which include mismatch repair (MMR) that recognizes base incorporation errors and base damage, base excision repair (BER) that removes damaged bases, nucleotide excision repair (NER) that removes bulky DNA adducts, and cross-link repair (ICL) that removes interstrand crosslinks [4]. Similarly, double strand DNA breaks also repaired by the two pathways viz. nonhomologous end joining (NHEJ) and homologous recombination (HR) [1]. The octa4 gene, also known as Pou5f1, is an important for various cell functions such as differentiation, embryonic growth etc.[5]. In the experimental condition, mitomycin c was used as a DNA damage agent [6]. It inhibits DNA synthesis by producing DNA crosslinks which halt cell replication and eventually cause cell death. Various drugs are available to reduce or restore DNA damage to normal via their antioxidant properties. One of such drug is metformin. It is peyquanide compound linked with guanidine and a ring of ammonia. The drug is routinly use to treat various diseases such as diabetes [7], polycystic ovaries syndrome [8], restore human DNA damage and carcinogenicity [9,10]. $\mathrm{Na}$ and Yoo [11] dreported metformin used for reduce DNA damage in the insect by protecting against oxidative stress and facilities for aging. Similarly, few plant extracts such as Hertia cheirifolia [12], Rhaponticum carthamoides [13]. Pinus densiflora [14] were also evaluated against DNA damage by various chemical agents $[15,16]$. Cyperus papyrus (Typhaceae) is growing in the southern Iraq marshes and in saline water [17], However, studies are very limited. So, there is a need for the better treatment for reducing the DNA damage cause by these various agents. With this background current study, aim to evaluate effect of Cyperus papyrus pollen 
grains on expression of octa4 gene in mitomycin c induced animal model.

\section{Patients and Methods}

Males Albino Rats, obtained from the Faculty of Veterinary Medicine / University of Baghdad at ages 10-12 weeks and weights (325-250) grams. The rats were subjected to appropriate laboratory conditions from a light cycle divided into 12 hours light and 12 hours darkness. Pollen grain powder was obtained from the local markets of the city of Nasiriyah and neighboring markets and was confirmed as locally produced known alKhrait. Collect the powder and place it in dishes of paper at room temperature. $(50 \mathrm{~g})$ of powder added to $500 \mathrm{ml}$ of distilled water to the boiling point and let cool with continuous stirring. Then filter the solution through layers of gauze, then filter paper. The effective dose was determined according to the method of [18]. The laboratory animals were divided into 6 groups and 4 animals per group were administered as follows for 30 days, the control group was injected with distilled water only as injected subcutaneous with distilled water. The second group was injected with mitomycin only with $10 \mathrm{mg} /$ $\mathrm{kg}$ injection by subcutaneous injection once a week. The third group gaved metformin at a concentration of $500 \mathrm{mg} / \mathrm{kg}$ by tubular feeding and mitomycin. The fourth group was injected with pollen grain water extract at a concentration of $50 \mathrm{mg} / \mathrm{kg}$ body weight with injected by mitomycin, the fifth group was injected with pollen grain water extract and metformin while sixth group injected by mitomycin and gaved metformin with pollen grain water extract. The rats were anesthetized and the kidneys and liver were excised and removed. Sections of the tissue were extracted and the DNA was extracted using a special extraction kit (USA kit extraction DNA Genomic), Which was processed by the United States Geneoid Company and was extracted according to the company's instructions The concentration and purity of the extracted DNA was assessed using the Nanodrop device, and the threeocta4 series was tested (the first package is $120 \mathrm{bp}$ and the second is $220 \mathrm{bp}$ ) and the third is the size of bp (410) a For forward sequence(5'CGACCTCCGTTCCTCTCCTC TATT-3')and reverse sequence(3'AGACGCACAAACCAAAACAAAATTAC A-5') [19]. The reaction conditions using polymerase chain reaction (PCR) were as follows:

Table (1): Conditions of polymerase chain reaction of the oct-4 initiator.

\begin{tabular}{|c|c|c|c|}
\hline Steps & Temperature & Time & Number of cycles \\
\hline Initial denaturation & $94 \mathrm{C}^{\circ}$ & $7 \mathrm{~min}$ & 1 \\
\hline Denaturation & $94 \mathrm{C}^{\circ}$ & $45 \mathrm{sec}$ & \multirow[t]{3}{*}{35} \\
\hline Annealing & $51 \mathrm{C}^{\circ}$ & $1 \mathrm{~min}$ & \\
\hline Extension & $72 \mathrm{C}^{\circ}$ & $1 \mathrm{~min}$ & \\
\hline Final extension & $72 \mathrm{C}^{\circ}$ & $7 \mathrm{~min}$ & 1 \\
\hline
\end{tabular}


The PCR reaction products were separated by the migration of a sample from each sample to the 2\% agrose gel as stated in Maniatis [20]. Lift the gel and was examined with a UV device and photographed for the purpose of study.

\section{Results}

In the present study, the expression of the oct4 transcription factor was studied in the rat treated with metformin and C. papyrus.

The effect was observed on three rat organs viz. liver, kidney and testes.

The kidney, liver and testes of healthy animals showed amplification of three bands. They are about 120, 220 and 410bp Figure (1). While, animals treated with mitomycin showed amplification of only two bands as compared to healthy control Figure (2). The third band which is about 410bp is missing in kidney, liver and testis of mitomycin treated animals.

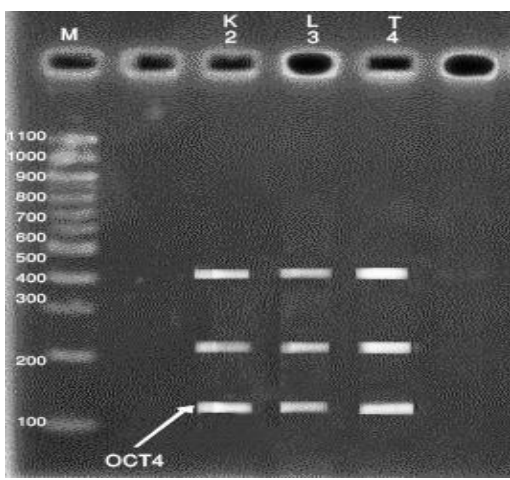

Figure (1): Control animals showed amplification of OCT 4 gene.

*K: Kidney, T: Testis, L: Liver, M: Marker (1Kbp)

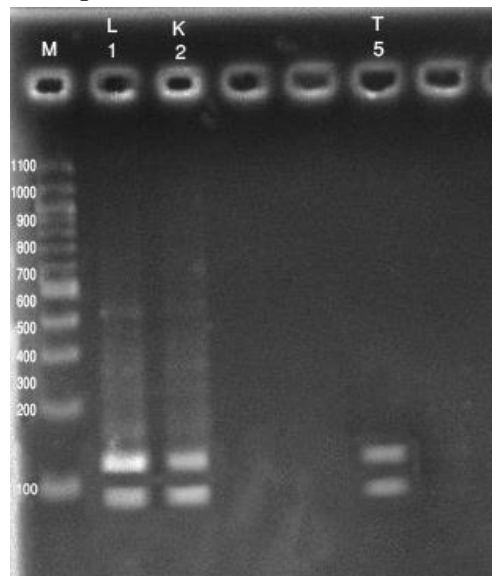

Figure (2):Amplification of OCT 4 gene in the mitomycin treated animals

*K: Kidney, T: Testis, L: Liver, M: Marker (1Kbp)

Animals treated with mitomycin along with metformin and pollen grains showed no amplification of all band only two dimar bands Figure (3). The individual treatment of metformin and pollen grains does not recover the normal pathophysiology. 


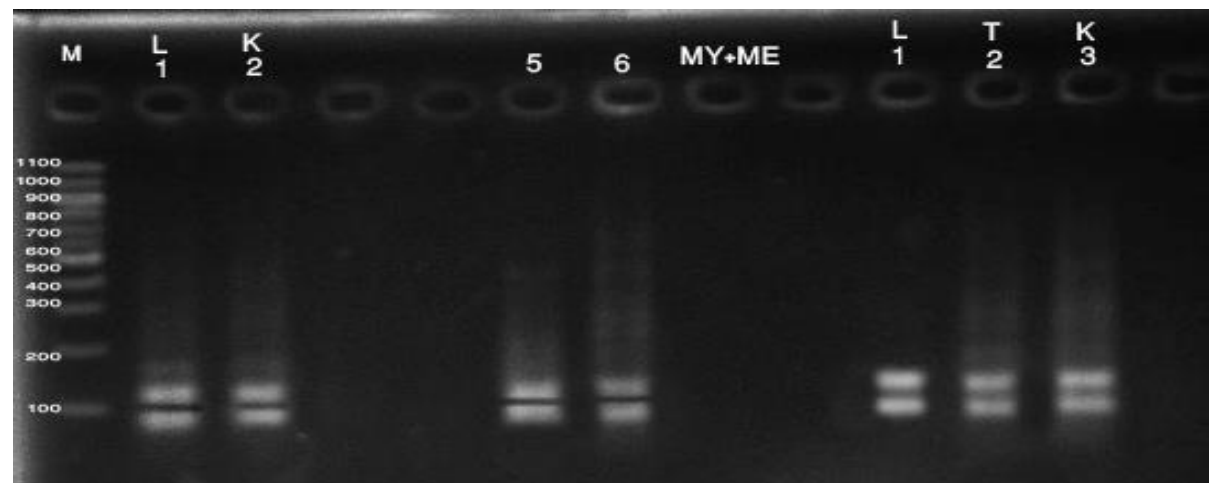

Figure (3): Amplification of OCT4 gene in animals treated with mitomycin along with metformin and pollen grains, respectively.

* P: Pollen grains, K: Kidney, T: Testis, L: Liver, M: Marker, MY: mitomycin, ME: metformin

Kidney and liver of animals treated with a complex structure of the testis tissue may not combination of mitomycin, metformin, have helped to introduce both metformin and pollen grains showed amplification of all pollen into the organ to protect it against the three bands (120, 220 and 410bp). The mitomycin C Figure (4).

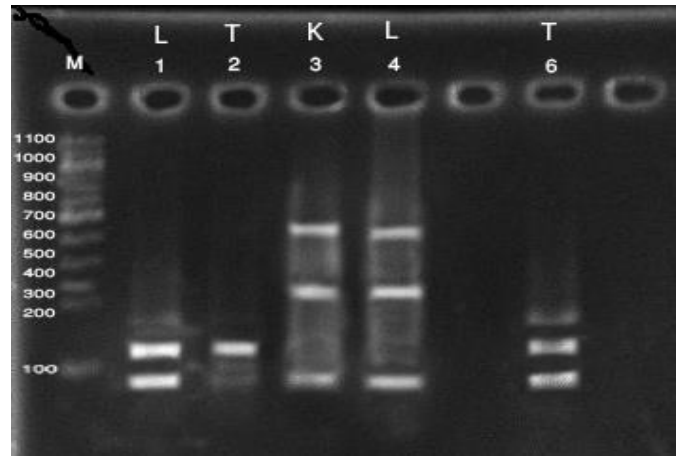

Figure (4): Amplification of OCT 4 gene in animals treated with a combination of mitomycin, metformin, pollen grains.

\section{Discussion}

Oct4 (encoded by Pou5f1) was first identified in mice as an ESC-specific and germline-specific transcription factor $[21,22,23]$. Oct4, a member of POU homeobox gene family, is a transcription factor capable of binding to an octameric consensus sequence to activate its target genes [11]. In humans, OCT4 is the product of the OTF3 gene, and three isoforms,
OCT4A, OCT4B and OCT4B1, have been reported [24].

Oct4 dosage is playing a key role in the murine embryonic carcinoma (mES) cell fate determination. Oct 4 concentration decides the mES for maintaining their pluripotency or towards differentiate lineages viz. trophoblast, primitive endodermal, mesodermal [5,25,26]. Several reports are 
available about the Oct 4 gene regarding its role in the cell proliferation [5,22,23,24,26]. The results showed the presence of three packages of the gene under study (the first package is $120 \mathrm{bp}$ and $220 \mathrm{bp}$ ) and the third was the size of bp (410) in both the kidney and liver tissue samples of the standard sample as in Figure (1).However, the absence of octa4 gene band does not appear in the rats genome ,the three bands that appeared in the standard samples are genetically modified, and the presence or absence there will be confirmed as evidence of the availability of both pollen extract and metformin in the preventio of mitomycin damage. The Figure (2) showed the treatment with mitomycin, the disappearance of the three band in each of the DNA samples of the kidneys and liver. This indicates a a damage in the genome, which led to the difficulty of knowing the initiator under study to the complementary areas of the gene. This is required. Mitomycin is used to cause this damage. High for this property and used [27],. The third group, which was injected with mitomycin and gaved pollen grain water extract, We note the inability of the pollen to prevent of damage to the gene. The results were similar in the group treated with mitomycin and metformin because metformin had no ability to prevent damage in each of the two organs under study Figure (4). While some studies indicated that metformin was able to prevent and repair damage His DNA [28]. This may be due to the inability of both kidney and liver tissue to metabolize metformin [29]. The fifth group, which was injected with mitomycin and stimulated with metformin, in addition to the water extract of pollen. This treatment showed a good prevent of the gene manifested by the re-emergence of the three bands as in the standard sample result. This confirms the enhancement of the pollen interaction between the pollen and metformin. This may be due to the fact that pollen contains effective anti-oxidant agents for pollen that can be diagnosed by containing substances that act as Scavenger free radicals and as inhibitors of lipid peroxidation. These substances interact with the free root of the compound (DPPH) 2,2diphenyl-1-picrylhydrazyl (DPPH) and reduce its effectiveness as a result of blocking the free radicals of this compound .

\section{References}

[1]Sirbu BM., Cortez D. DNA Damage Response: Three Levels of DNA Repair Regulation. Cold Spring Harbor Perspectives in

$$
\text { Biology,2013, }
$$
$5(8)$,

10.1101/cshperspect.a012724.

[2]Trosko JE . From adult stem cells to cancer stem cells: Oct-4 Gene, cell-cell communication, and hormones during tumor promotion. Ann N Y Acad Sci.,2006, 1089:36-58.

[3]Gaulden ME, Ferguson MJ, Seibert GB, Proctor BL. Mitomycin $\mathrm{C}$ effects on cell cycle progression, including inhibition of very late prophase, as seen in living neuroblasts of Chortophaga viridifasciata, with some observations on mitomycin $\mathrm{C}$ purity. Mutat Res. Mar;1985, 149(1):41-50. [4]Kruhlak MJ, Celeste A, Dellaire G, Fernandez-Capetillo O, Müller WG, 
McNally JG, Bazett-Jones DP, Nussenzweig A Changes in chromatin structure and mobility in living cells at sites of DNA double-strand break.s. J Cell Biol. , 2006 ,172(6):823-34.

[5]Zeineddine D, Papadimou E, Chebli K, Gineste M, Liu J, Grey C, Thurig S, Behfar A, Wallace VA, Skerjanc IS, Pucéat M. Oct3/4 dose dependently regulates specification of embryonic stem cells toward a cardiac lineage and early heart development. Dev Cell. 2006;11:535-46.

[6]Lee YJ, Park SJ, Ciccone SLM, Kim $\mathrm{CR}$, Lee $\mathrm{SH}$.An in vivo analysis of MMCinduced DNA damage and its repair. Carcinogenesis, 2006, 27(3):446-453.

[7]Lapolla, A. ; Dalfrà, M. G.; Ragazzi, E. ; De Cata, A. P. and Fedele, D. New International Association of the Diabetes and Pregnancy Study Groups (IADPSG) recommendations for diagnosing gestational diabetes compared with former criteria: a retrospective study on pregnancy outcome. Epidemiol.,2011,.28 (9):1074-1077.

[8]Anglico , F. ; Burattin , M.; Alessandri, C. ; Delben, M. and Lirussi, F. Drugs improving insulin resistance for non alcoholic fatty liver disease and or non alcoholic state hepatitis . Cochrane ,J, Syst, Rev, 2007 ,24(1) : 10-75.

[9]Amador,R.R. J.P. Longo, Z.G. Lacava, J.G. Dorea, F. Almeida Santos Mde,Metformin (dimethyl-biguanide) induced DNA damage in mammalian cells,Genet. Mol. Biol. ,2012,35: 153-158. [10]Lee YS; Doonan BB; Wu JM and Hsieh TC. Combined metformin and resveratrol confers protection against UVC-induced DNA damage in A549 lung cancer cells via modulation of cell cycle checkpoints and DNA repair. Oncol Rep. 2016 Jun;35(6):3735-41.

[11]Na, $\mathrm{H}$ and Yoo,M Mechanisms of Agening and development.Sci. Dir.134(9),2013:381-390.

[12]Kada S, Bouriche H, Senator A, Demirtaş I, Özen T, Çeken Toptanci B, Kızıl G, K1zıl M .Protective activity of Hertia cheirifolia extracts against DNA damage, lipid peroxidation and protein oxidation. Pharm Biol. , 2017 ,55(1):330-337.

[13]Skała, E., Sitarek, P., Różalski, M., Krajewska, U., Szemraj, J., Wysokińska, H., \& Śliwiński, T. Antioxidant and DNA Repair Stimulating Effect of Extracts from Transformed and Normal Roots of Rhaponticum carthamoides against Induced Oxidative Stress and DNA Damage in $\mathrm{CHO}$ Cells. Oxidative Med. and Cell. Long., 2016, 5753139.

[14]Jiang Y., Han, W., Shen, T., \& Wang, M.-H. Antioxidant Activity and Protection from DNA Damage by Water Extract from Pine (Pinus densiflora) Bark. Preventive Nutrition and Food Science, 2012 , 17(2), 116-121.

http://doi.org/10.3746/pnf.2012.17.2.116

[15]AL-Khan, H. I. Effect of Aqueous Extract of Capparis spinose on serum Antioxidant Status in Paracetamol Treeated Rats. Jou. Raf. Sci.,2010 , 21(2):29-36. [16]Tsuchimatsu, T. and Shimizu, K. K. Effect of Pollen Availability and Mutation Bias of Fixation of Mutations Disabling The 
male Specificity of Self-Incompatibility .J. Evol. Biol.,2013, 26(10):2221-32.

[17]Al-Hadeethi, M. A.; Al-Obaidi, B. M.; Hamadi, S S.; Al-Rikabi, R. H.(2016) Comparative Anatomical Study between Typha domengensis and Phragmites communis. Ibn Al-Haitham J. for Pure \& Appl. Sci, Vol. 29 (2):320-330.

[18]Naciri, M, ; Buchner,B; Bunnik,T ; Huijsmans, R \& Andrews,J "Low Frequency Motions of LNG carriers in shallow water", Proceedings of 2004 Offshore Mechanics \& Artic Engineering Conference. Paper OMAE200451169. 5

[19]Darini,C. Y. ; DF Pisani, D. F.; Hofman, P.; Pedeutour, F. ; Sudaka, I. ; Chomienne, C. ; Dani, C. ; Ladoux, A. Self-renewal gene tracking to identify tumour-initiating cells associated with metastatic potential. Onc.,2011 : 1-12.

[20]Maniatis, t. E. ;Fritssch, E. F. and Samberook, j. (1982) Molecular cloning Laboratory manual. Cold Spring Laboratory ,NY:545.

[21]Rosner MH, Vigano MA, Ozato K, Timmons PM, Poirier F, Rigby PW, Staudt LM. A POU-domain transcription factor in early stem cells and germ cells of the mammalian embryo. Nature. 1990;345:686692. doi: 10.1038/345686a0.

[22]Scholer HR, Ruppert S, Suzuki N, Chowdhury K, Gruss P. New type of POU domain in germ line-specific protein Oct-4. Nature. $\quad$ 1990;344:435-439. doi: $10.1038 / 344435 \mathrm{a} 0$.

[23] Okamoto K, Okazawa H, Okuda A, Sakai M, Muramatsu M, Hamada H. A novel octamer binding transcription factor is differentially expressed in mouse embryonic cells. Cell. 1990;60:461-472. doi: 10.1016/0092-8674(90)90597-8.

[24]Wang X, Dai J. Concise review: isoforms of OCT4 contribute to the confusing diversity in stem cell biology. Stem Cells. 2010;28:885-893. doi: 10.1002/stem.542.

[25]Niwa H, Miyazaki J, Smith AG. Quantitative expression of Oct-3/4 defines differentiation, dedifferentiation or selfrenewal of ES cells. Nat Genet. 2000;24:372-6.

[26]Stefanovic S, Puceat M. Oct-3/4: not just a gatekeeper of pluripotency for embryonic stem cell, a cell fate instructor through a gene dosage effect. Cell Cycle. 2007;6:8-10. [27]Becerril, $\mathrm{C}$; Ferrero, $\mathrm{M}$;Sanz, $\mathrm{F}$ ;Cãtaño, A Detection of Mitomycin C Induced Genetic Damage in Fish Celles by Use RAPD. Mut. 1999, 14(5): 449-456.

[28]Na, H-J ;Park, J-S ; Pyo, J-H ;Lee, S-H ;Jeona, H-J ;Kim, Y-S ; Yoo, M-A Mechanism of metformin: Inhibition of DNA damage and proliferative activity in Drosophila midgut stem cell. Mech. of Ag. and Devel. , 2013, 134, Issue 9: 381-390.

[29]Pawlyk, A C; Giacomini, K M; McKeon, C; Shuldiner, A R ; Florezcorresponding, J C.(2014). Metformin Pharmacogenomics: Current Status and Future Directions. Diabetes,2014, 63(8): 2590-2599. 